\title{
The Science of Nature - a new era, a new name for Naturwissenschaften
}

\author{
Sven Thatje
}

Received: 1 December 2014 / Accepted: 3 December 2014 / Published online: 30 January 2015

(C) Springer-Verlag Berlin Heidelberg 2014

It is my great pleasure to introduce the journal The Science of Nature. Formerly known as Naturwissenschaften, the journal looks back on over 100 years of publishing scientific work from around the world. The former German title has been kept as the subtitle to The Science of Nature in recognition of the journal's long distinguished history (Thatje 2013).

At the same time, Continuous Article Publishing (CAP) has been implemented to shorten publication time for all contributions, following the current trend in electronic publishing. The journal's scope remains at the heart of the natural sciences. It promotes the very best research and contributes to deeper insights in the broad field of the biological sciences. The Science of Nature, as did Naturwissenschaften, includes contributions from the chemical, geological, and physical sciences, as long as these contribute to questions of general interest to the broader community in the biological sciences (Thatje 2014).

The changes will present the journal as a modern twentyfirst century publishing tool, offering the global scientific community the highest possible standards. The journal's ability to quickly respond to the ever-faster moving developments in the natural sciences will be greatly enhanced, and its overall visibility and international competitiveness will improve significantly.

I am very pleased to have the opportunity to lead the journal through this important transition period. I cordially invite you to actively contribute to the journal's future, either as authors and/or reviewers, and to follow the development of

S. Thatje $(\bowtie)$

Ocean and Earth Science, University of Southampton, European

Way, Southampton SO14 3ZH, UK

e-mail: svth@noc.soton.ac.uk
The Science of Nature in the years to come.

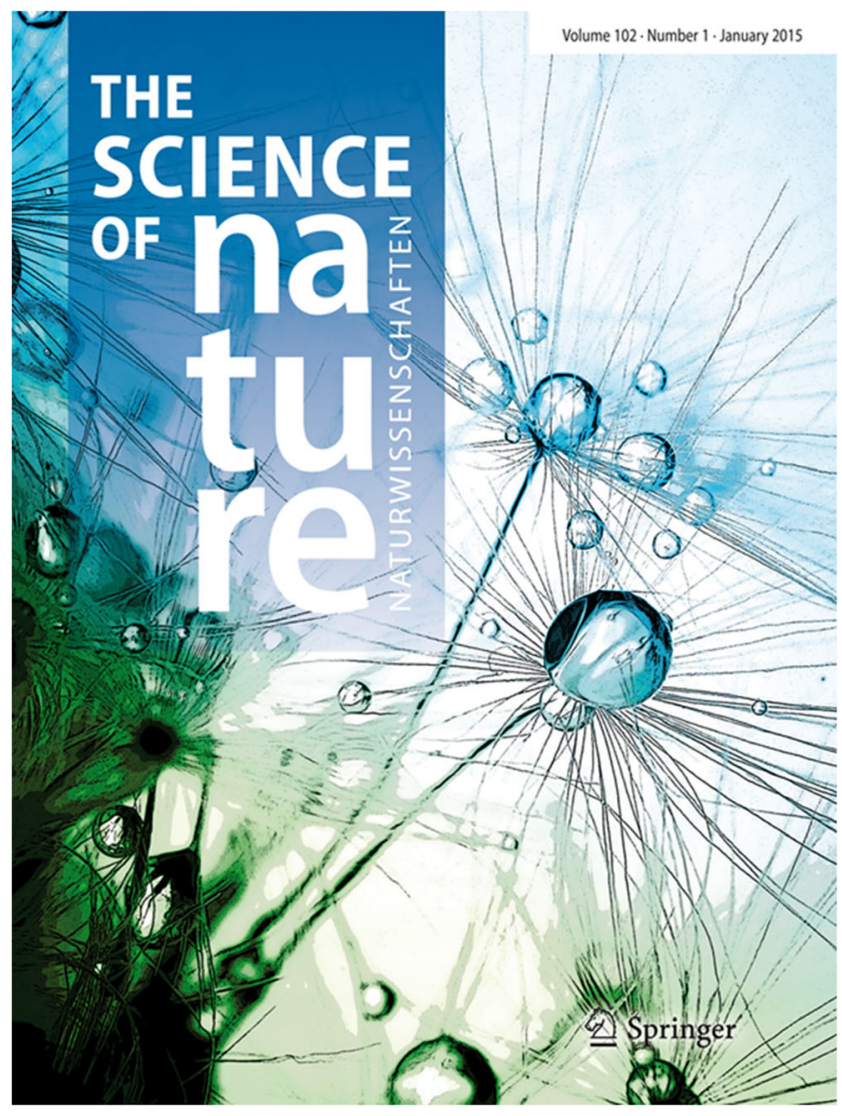

\section{References}

Thatje S (2013) Celebrating 100 years: happy birthday, Naturwissenschaften! Naturwissenschaften 100:1

Thatje S (2014) Moving forward: change of journal title and continuous article publishing. Naturwissenschaften 101:1007-1008 